\title{
Shining a light on fossil fuel subsidies at the WTO: how NGOs can contribute to WTO notification and surveillance
}

\author{
LIESBETH CASIER \\ International Institute for Sustainable Development, Geneva \\ ROBIN FRASER \\ School of Policy Studies, Queen's University \\ MARK HALLE \\ International Institute for Sustainable Development, Geneva \\ ROBERT WOLFE* \\ School of Policy Studies, Queen's University
}

\begin{abstract}
Fossil fuel subsidies undermine efforts to mitigate climate change, and they damage the trading system. Multilateral discussion is hampered by inconsistent definitions and incomplete data, which could increase the risks of WTO disputes. Members do not notify such subsidies as much as they should under the Agreement on Subsidies and Countervailing Measures (ASCM), which limits the usefulness of the SCM Committee. The reports of the Trade Policy Review Mechanism on individual countries and on the trading system draw on a wider range of sources, creating an opportunity for non-governmental organizations (NGOs) to provide the missing data from publicly available sources. We suggest a new template that could be used for such third-party notifications. The objective is to shine a light on all fossil fuel subsidies that cause market distortions, especially trade distortions. The result should be better, more comparable data for the Secretariat, governments, and researchers, providing the basis for better-informed discussion of the incidence of fossil fuel subsidies and rationale for their use.
\end{abstract}

Energy subsidies can foster sustainable development, just as they can undermine it. Sustainable development cannot be left on the shelf as a grand aspiration to be trotted out when leaders need to make an inspirational speech. It has to be built from the bottom up in full knowledge of the intricate detail of the

*(Corresponding author). Email: robert.wolfe@queensu.ca

\footnotetext{
We are grateful for the comments and advice of Terry Collins-Williams, Luca Rubini, Ronald Steenblik, an anonymous reviewer, and colleagues in the IISD Global Subsidies Initiative, none of whom is responsible for our interpretations and mistakes; and for the support of the ENTWINED research consortium, a project funded by the MISTRA Foundation of Sweden.
} 
multilateral system. Disciplines on energy subsidies are weak, but the World Trade Organization (WTO) could offer more analysis and opportunities for discussion of reform. The first step is making more information available about fossil fuel subsidies. This paper offers a proposal on how to achieve that objective.

Global fossil fuel subsidies are estimated to run at more than US\$600 billion each year (GSI, 2013a). These subsidies, found in both developed and developing countries, significantly undermine sustainable development, presenting both a lost opportunity to spend government funds on other development priorities and an obstacle in the transition to a low-carbon future. In addition to encouraging carbon emissions, fossil fuel subsidies burden government budgets, create market distortions, and often do not meet the goals for which they were designed in the first place, such as providing energy access to the poor. In the absence of a global price on carbon, it is imperative that we develop a more accurate picture of such subsidies, ideally in a context where governments can discuss the rationale for their use and the prospects for reform.

Governments increasingly acknowledge the need to do something about fossil fuel subsidies, at least those that, according to G-20 Leaders, 'encourage wasteful consumption, reduce our energy security, impede investment in clean energy sources and undermine efforts to deal with the threat of climate change' (G-20, 2009). The International Energy Agency (IEA) and the Organization for Economic Cooperation and Development (OECD) now publish regular estimates of budgetary support and tax expenditures for fossil fuel in developing and developed countries, while the World Bank and the International Monetary Fund (IMF) are increasing the level of support offered to developing countries to assist their national reform processes. Over 110 countries mentioned fossil fuel subsidy reform in their submissions to the preparatory process for the 19th Conference of the Parties to the UN Framework Convention on Climate Change; however, binding international commitments to reform fossil fuel subsidies are unlikely in the near term. Identifying a new pathway to achieve practical results would focus the efforts of civil society and government champions.

Although many experts argue that energy should have a central place within the WTO, potentially in a separate agreement covering its different trade-related aspects (Cottier et al., 2011; ICTSD, 2011), currently the rules applicable to energy, including energy-related goods and services, are to be found in different agreements: the General Agreement on Tariffs and Trade (GATT), the Agreement on Subsidies and Countervailing Measures (ASCM), the General Agreement on Trade in Services (GATS) and the Agreement on Agriculture. All goods sectors are covered by the ASCM, but the applicability of the rules to fossil fuel subsidies is not clear. Nevertheless, we think that the WTO offers an appropriate forum for addressing issues relating to such harmful subsidies.

Fossil fuel subsidies, both to producers, often in rich countries, and to consumers, often in poor countries, have the potential to distort markets and resource allocation and hence trade flows, not least in industries for 
which energy is an important intermediate input, such as steel, aluminum, glass, and cement (Steenblik, 2010). To the extent that they subsidize final consumption of fossil fuels, such subsidies can increase imports, which is not normally seen as harming trade. Nevertheless, while injury to specific firms or trading partners may be hard to establish, the harm to the trading system is clear.

The inclusion of fisheries subsidies on the agenda for the Doha Round set a precedent for negotiations on subsidies that have negative impacts beyond trade distortion. Reaching consensus on the fact that fisheries subsidies represented a suitable subject for WTO negotiations took years of effort by international organizations, governments, and NGOs. First was the patient work of the Food and Agriculture Organization of the United Nations (FAO), United Nations Environment Programme (UNEP), regional fishery commissions, and the OECD in gathering information on the state of fish stocks and monitoring the effects of fishery operations. Second was a series of multilateral agreements that began to build a governance regime for fishery management. Third was the building of an unconventional alliance of countries concerned with the impact of fish subsidies on efforts to manage fish stocks sustainably. Fourth was the analytic and campaigning power of civil society groups such as the World Wildlife Fund (WWF) and the International Centre for Trade and Sustainable Development (ICTSD). These groups demonstrated the need for reform, reframed the issue in WTO language, and created pressure for action. The lesson is simple: without careful scientific and political preparation, and without the formation of effective alliances, new issues brought to the WTO are unlikely to be accepted or, where they are, to advance (Steenblik, 1998).

The inability to conclude the fisheries subsidies negotiations suggests, however, that formally binding rules on fossil fuel subsidies may not be achievable in the near term. The recent disputes on renewable energy similarly suggest that reliance on litigation to clarify rules deliberately left ambiguous by Members may also not be the best solution (Rubini, 2012: 558). We believe that Members, rather than the Appellate Body, should set the scope for bad or good subsidies (Casier and Moerenhout, 2013), but if Members do not begin to discuss the problem, the Appellate Body may be solicited more often in future. It would be perverse to leave many fossil fuel subsidies undisciplined while support for the development of renewable energy is further entangled in complex rules (Meyer, 2013). If the WTO is to play a role, however, it will have to be within existing rules. Better transparency could help.

Trade policy transparency is an important tool for advancing policy objectives and a non-coercive instrument for improving the operation of the trading system (Wolfe, 2013). One of the questions in any international legal regime is the extent to which differing national laws are functionally or recognizably similar. Transparency mechanisms allow an assessment of whether national law, policy, and implementation are consistent with a Member's obligations. Such transparency is also the basis for one actor to try to influence another actor to act differently. 
As a result of questions and challenge in a committee, a government may provide more information, change policy, or pressure other units of government to respond. Using WTO mechanisms for transparency and surveillance would allow Members to discuss and negotiate the incidence and logic of subsidies instead of filing one dispute after another. The ASCM should be a useful tool, but this agreement is less effective than it ought to be: Members fail to either notify their subsidies, or notify only sporadically, and late. Inadequate transparency and surveillance in the Subsidies and Countervailing Measures (SCM) Committee increases the risk of resort to the dispute settlement system. An alternative is needed.

We begin in the next section by clarifying what is meant by 'subsidy', and how that shapes the information available on fossil fuel subsidies. Our alternative to reliance on dispute settlement to clarify WTO rules focuses on improving transparency and surveillance, which we believe is more feasible given the current state of negotiations in the Doha Round, but Members are unlikely to notify all their fossil fuel subsidies to the SCM Committee. One way to encourage notification of such subsidies would be to allow them to be potentially 'non-actionable' under Article 8 of the ASCM, but this article lapsed in 2000; in the second section, we show why it is unlikely to be restored. In the third section, we suggest that the Trade Policy Review Mechanism (TPRM) offers a better immediate forum. We show that the TPR Secretariat has the ability to use information from a wide variety of sources, which creates an opportunity, discussed in the fourth section, for non-governmental organizations (NGOs) to provide such third-party notifications. For data to be useful, they ought to be provided in a standard format; in the fifth section, we propose a new template that NGOs could use to notify publicly available information on fossil fuel subsidies to the WTO. We believe the WTO offers both a framework and mechanisms for reviewing a broad range of traderelated policies. In the conclusion, we discuss the broader implications of how such engagement with civil society can contribute to the functioning of the WTO. Improving the existing transparency and surveillance mechanisms would allow Members to discuss both subsidies that foster sustainable development and inefficient subsidies that present a threat to the trading system, energy security, and the global climate.

\section{What is a subsidy? And what data are available?}

This paper depends on two conceptual steps. First, we need a definition of 'subsidy'. The notion that some actions of governments are subsidies and others not may seem simple in economic theory, leading to claims that one definition would do, but in practice definitions serve particular policy and analytic purposes. What can be measured-and disciplined-depends on those definitions. Second, the availability of data has been shaped by the definitions, with the result that some debates about the extent and scope of energy subsidies are due to variations in how they are measured (Steenblik, 2010). In thinking about a definition, we need not 
work though the full complexity of the meaning of the term (Jones and Steenblik, 2010), but we need to make it operational for our purposes. That is, we should be able to identify fossil fuel subsidies, with common metrics to allow comparison.

The international organizations charged with action on fossil fuel subsidies differ in their definitions and in their calculation method. Some overlap; some parts are significantly different. The WTO definition of subsidies in general is based on legally binding reciprocal obligations aimed at improving the conditions of multilateral trade through disciplines on government policy. Other international organizations have more latitude to use specific definitions of fossil fuel subsidies designed for analytic purposes or, especially in the case of the International Monetary Fund (IMF), to support a process of domestic reform. In this section, we describe how each organization defines subsidies in general or fossil fuel subsidies in particular. We conclude the section with a discussion of the implications for the availability of data.

\section{Organization for Economic Cooperation and Development (OECD)}

Since its inception as the Organization for European Economic Cooperation (OEEC), the OECD has been concerned about state support to economic actors, but the Secretariat avoids the word 'subsidy' because of the link with the WTO legal agreements. Differences between sectors mean that it does not have a single definition, but it does apply a common approach based on Producer Support Estimates (PSE) and Consumer Support Estimates (CSE).

In its assessment of agricultural support, the OECD chose to make a distinction between PSE and CSE. While the former consist of support to agriculture producers, the latter measure transfers to consumers of agricultural commodities (OECD, 2010). The same concept is now being used for fossil fuels. The OECD measurement of support for fossil fuels includes both direct budgetary expenditures and tax expenditures that in one way or the other provide a benefit or lead to a preference for fossil fuel production or consumption in comparison with alternatives. The OECD Secretariat admits that for analytic reasons, the scope of what is considered 'support' is deliberately broader than some conceptions of 'subsidy' (OECD, 2012: 20). For example, the inventory includes 'general service' expenses arising as a result of coal mining and the transition away from coal mining in European countries, including early retirement payments for coal miners, support for decommissioning and restructuring of the coal mining industry, and even programs financing remediation of environmental damage caused by coal mining. Such programs would likely not fall within the WTO or IEA definitions or indeed the conventional understanding of fossil fuel subsidies; nevertheless, as the OECD approach urges, transparency about the measures taken is a necessary first step.

The OECD database has other limitations. Measuring tax expenditures is less straightforward than measuring direct budgetary expenses, which can be readily identified from government accounts. To calculate the tax expenditures, a 
benchmark has to be used. This benchmark is country dependent because every country has a different perspective on the 'normal' taxation against which fossil fuel taxation is measured. The benchmark is also highly dependent on the nature and role of the overall taxation system of a country. In consequence, the inventory was not designed for international comparability (OECD, 2012: 32-36).

The OECD Inventory also does not yet include estimates of government support provided through risk transfers, concessional credit, and injections of funds into state-owned enterprises. Market price support (transfers from consumers and taxpayers to energy producers arising from policy measures creating a gap between domestic producer prices and reference prices of a specific energy commodity) is also not included for the moment (OECD, 2012: 22), mainly because it is no longer provided by OECD countries. Transfers through price gaps on the consumer side do not exist in OECD countries, with the exception of Mexico, but are included in the estimates of fossil fuel (consumption) subsidies by the IEA. ${ }^{1}$

\section{International Energy Agency (IEA)}

The International Energy Agency approach to measuring fossil fuel consumption subsidies is based on the price-gap approach, whereby the national end price to consumers is compared to an international reference price. When the international reference price is higher than the end-user price, the difference is assumed to be due to a subsidy. While this method is relatively straightforward, the disadvantages have to be kept in mind (IEA, 2013).

First, discussions continue on the calculation of the reference price. Second, this method will not capture a subsidy that is not reflected in the end-user price of the fossil fuel. For example, governments can decide to subsidize domestic oil and gas producers who in turn use the subsidies for new technologies or for exploring hydrocarbon resources that they could otherwise not afford to develop. These actions, however, do not necessarily lead to a change in the market price of fossil fuels, yet they are clearly subsidies (Koplow, 2009). Third, in many OECD countries end-user prices are set at the reference price level, or even above due to taxes, which does not mean that no subsidies for fossil fuels exist in these countries.

The IEA captures fossil fuel consumption subsidies in developing countries and emerging economies, most of which have not yet been estimated by the OECD, but leaves out the subsidies of developed countries, including those of IEA Members. The two datasets are therefore to some extent complementary. The IEA data are only quantitative and not well documented, while the OECD Inventory gives an

1 The Panel in the Canada-Renewable Energy (WTO, 2012a) case dodged the question of whether such measures constitute price support. Based on the findings of the Panel in China-GOES (WTO, 2012d), however, these measures are arguably price support as defined in the ASCM. The Panel states that price support refers to measures to keep producer prices above a certain minimum. Read in the context of the ASCM there needs to be some indication of direct government intervention in order not to define all governmental measures with an incidental effect on market prices as a subsidy under the ASCM. 
overview of the policy measures behind the numbers as well. The IEA data come from market calculations carried out by the IEA while the data of the OECD come from documented government sources. Both include the amount of the subsidy but the OECD's information is more complete and more useful because it not only reports on the amount of the subsidy, as the IEA does, but also provides information on the department that is responsible for the subsidy, what type of subsidy it is (tax exemption or direct transfer), the conditions for getting the subsidy, and so on. The IEA does not provide this information.

\section{International Monetary Fund (IMF)}

The IMF defines energy subsidies in a broad way to include both production and consumption subsidies (Clements et al., 2013). The IMF first calculates consumption subsidies according to the price-gap method (drawing in part on IEA estimates). They then add budgetary support to producers (currently estimated by the OECD) in what the IMF calls a pre-tax subsidy: the extent to which the price that the consumer pays is below supply and distribution costs. In a second step, the IMF also estimates for each country what it calls a post-tax subsidy to draw a full picture of the degree of under-pricing. A post-tax subsidy is deemed to exist if the tax on fossil fuels is below the IMF's rough approximation of its efficient level. For the IMF, efficient taxation would require that (1) all consumption of fossil fuels is subject to taxation, and (2) that a corrective tax is introduced to capture the negative externalities of fossil fuel consumption, including externalities not directly proportional to fuel use, such as the costs of traffic accidents and congestion. Thus, the main difference between the IMF estimates and the OECD is the former's inclusion of a corrective tax for negative externalities.

\section{The Group of Twenty Leaders' Summit (G-20)}

Definitional ambiguity bedevils the commitments made by G-20 Leaders in 2009 to phase out inefficient fossil fuel subsidies that encourage wasteful consumption. ${ }^{2}$ Their Working Group on Energy and Commodity Markets, which is responsible for progress on the commitment, has not agreed on a definition, which leaves G-20 Members with discretion to use their own definition, with the unsurprising result that 11 Members claimed that they had no inefficient fossil fuel subsidies to report (Koplow, 2012; GSI, 2013b). It is unclear what kind of subsidies countries do address in their voluntary reports, which are incoherent and do not give a proper overview of the fossil fuel subsidies of a country. In order to improve progress on the commitment, at the 2012 Summit in Los Cabos, G-20 leaders requested that Finance Ministers develop a voluntary peer review process to increase transparency

2 The exact language was agreement 'To phase out and rationalize over the medium term inefficient fossil fuel subsidies while providing targeted support for the poorest. Inefficient fossil fuel subsidies encourage wasteful consumption, reduce our energy security, impede investment in clean energy sources and undermine efforts to deal with the threat of climate change' (G-20, 2009). 
in the fossil fuel subsidies debate. Different forms of peer-review mechanisms have been discussed by the Working Group; in a first step, China and the United States committed in December 2013 to initiate reciprocal peer reviews. G-20 peer review may eventually provide a forum in which officials can discuss issues related to fossil fuel subsidies, but is unlikely to lead to a significant increase in reporting of subsidies in the short term, although the peer review teams might refer to data reported elsewhere.

\section{World Trade Organization}

Nobody doubts that subsidies can have an effect on trade, and subsidies were covered in GATT 1947, but negotiators were unable to devise a practical definition of subsidy until the conclusion of the Uruguay Round in 1994. The first part of the definition of a subsidy in Article 1.1 of the ASCM requires a financial contribution or price or income support provided by the government. The finite list of types of financial contributions includes: when a government transfers funds directly; when government revenue that is otherwise due is foregone or not collected; when a government provides goods or services below the market rate or purchases above the market rate; or when a government works through a funding mechanism to provide any of the aforementioned financial contributions. This list is the basis for the left-hand column of the GSI energy subsidies checklist found in Appendix 1 below. The second part of the definition, Article 1.2, requires that a benefit be conferred to the recipient, which entails an exercise of comparison between a situation in which a recipient receives the financial contribution and one in which it does not.

Both Articles 1.1 and 1.2 imply that certain economic support measures do not fall under the scope of the ASCM and are therefore unregulated by the WTO, and do not need to be notified. The ASCM classified subsidies as either prohibited, actionable, or non-actionable. Two categories of subsidies, import substitution and export subsidies, are prohibited (Article 3). In order for a Member to take action against a 'harmful' subsidy of another Member, a subsidy has to be specific (Article 2) and the adverse effects have to be demonstrated (Article 5 and 6). (We will have more to say on the non-actionable category below.)

The subsidy definition is designed to be applied by Members either in notifying specific subsidies to the SCM Committee (Article 25), in the application of countervailing duty measures (ASCM Part V), and in making a complaint in the dispute settlement system. The SCM Committee is mandated to examine these subsidy notifications on a regular basis (Article 26). Under Article 25.8 of the ASCM, Members are allowed to request information on subsidies that they think another Member was obliged to notify, and Article 25.10 provides a formal mechanism through which Members can counter-notify subsidies of another Member.

This definition is sufficiently ambiguous with respect to both specificity and benefit to the recipient that Members are not always clear about what it covers, and the jurisprudence is confusing. In the Canada-Renewable Energy case, for example, both the original panel and the Appellate Body struggled with finding 
the appropriate benchmark for comparison, with insufficient evidence to demonstrate that a benefit was conferred. ${ }^{3}$ The Panel also could not agree on the definition of a subsidy, resulting in a dissenting opinion of one panelist. On appeal, the Appellate Body avoided ruling on whether the disputed measure, Ontario's Feed-In Tariff program, constituted a subsidy (WTO, 2012a; WTO 2013a; see also Casier and Moerenhout, 2013). This conceptual ambiguity is not new, and it affects the quality and amount of information available from WTO notifications. Only subsidies that meet the ASCM definition have to be notified, but when a benefit analysis is inconclusive, Members may decide not to notify the measure, although ideally when in doubt, they ought to notify.

Early on, the SCM Committee designed a questionnaire for subsidy notifications under Article 25 and established procedures for annual Committee review of notifications (WTO, 2003d). It soon became apparent, however, that WTO Members, including many of the largest developed Members, were woefully deficient in meeting the notification obligations - and they still are (WTO, 2006, $2012 \mathrm{~b}$ ). Given the inadequacies and ambiguities of the notification questionnaire derived from the ASCM, the poor quality of the data is not surprising.

The SCM questionnaire states that the following subsidies are subject to notification: 'a) all specific subsidies ... and b) all other subsidies, which operate directly or indirectly to increase exports.... The legal text and the jurisprudence fail, however, to clarify the conditions under which subsidies are specific. Indeed the concept lacks any real economic justification: it is just an administrative - and pliable - tool to select measures (Rubini, 2009: 359-366). The distinction between a specific and non-specific subsidy in economic terms does not seem to make much sense. A subsidy that is used to correct a market failure might well be as effective (or more effective) when targeted at particular industries or enterprises than a generally available subsidy (Howse, 2010). The general rule is that specific subsidies are those that only apply to certain enterprises. The Article explains that only when conditions for eligibility of a subsidy are clearly defined in law can a subsidy be specific. But even if that is not the case, a subsidy can be de facto specific if a particular industry or sector benefits disproportionally.

Also difficult is that part of the questionnaire that requests 'Statistical data permitting an assessment of the trade effects of the subsidy'. Whether a subsidy has trade effects requires a judgment by the notifier, one that does not lend itself to a quick assessment by government officials - not surprisingly, such data (which may

3 The $\mathrm{AB}$ stated that for a finding of a benefit one has to (1) define the relevant market and (2) find the appropriate benchmark within that market. After defining that the relevant market was the market for renewable energy-despite the substitutability of electricity produced by renewable and conventional energy sources - the $\mathrm{AB}$ determined the benchmark to be found in a competitive market for solar and wind energy with the characteristics of Ontario's market. It eventually concluded that due to the 'complexity of the issues ... and the absence of full exploration of the issues before the panel' it could not determine whether a benefit was conferred (paragraph 5.244 of the $\mathrm{AB}$ report) 
be perceived as a confession inviting a dispute) are rarely provided (CollinsWilliams and Wolfe, 2010). But Members do notify all kinds of subsidies, both ones that are clearly specific, and ones that might be general at first sight but may be specific when taking into account all elements for the application of the subsidy. Given the different, incomplete and sometimes unclear notifications that Members have submitted to the WTO, it seems Members are not clear on what the definition covers and as a consequence are unclear on which subsidies they ought to notify. ${ }^{4}$ Rubini (2012) argues that in line with the EU approach to state aid, governments might choose to notify all subsidies instead of going through the unclear assessment of whether a subsidy is specific. Such notification will allow questions to be asked in the Committee.

\section{Summary: comparing definitions and data}

Given these differing definitions used by international organizations, it is hardly surprising that what they report differs. The IEA, reflecting its long expertise in monitoring energy markets, uses market data and can, as a result of its methodology, miss government measures that clearly amount to economic support, or it might include elements that constitute a price gap that is not caused by government action.

Definitional ambiguities notwithstanding, our review of notifications under the ASCM found that Members have sporadically notified a variety of support measures (grants, loans, tax and excise exemptions, and others) that amount to fossil fuel subsidies, even if not labeled as such. The United States and Japan have been particularly forthcoming; the United States even notified several sub-federal subsidization programs, notably an oil- and gas-production tax credit offered by the state of Alaska to promote oil exploration and drilling. The notified Japanese measures were mostly related to overseas oil and gas exploration and to research and development (R\&D). India has notified several sub-federal fossil fuel subsidy programs in the fishery sector, typically consisting of rebates on fuel taxes for 'poor fishermen'. (Fuel subsidies, which may account for $20 \%$ of fisheries subsidies, were a major sticking point in the Doha Round negotiations.) The most recent Russian subsidy notifications include only one fossil fuel program, although independent researchers have been able to identify a range of fossil fuel subsidies based on the SCM definition (Gerasimchuk, 2012).

The OECD Inventory (OECD, 2012) relies on publicly available government data, which is information that could have been notified to the WTO. A comparison found that in most cases the OECD Inventory covered many more support measures than the WTO notifications, and in more detail, as shown in Appendix 3. Where the OECD inventory contains 640 measures for the 2008-2013 period,

4 Compare the large difference between the German subsidies identified by Thone and Debroschke (2008) and the subsidies Germany notified to the WTO. 
the WTO has only 64. Particularly on the sub-federal level, the OECD Inventory, compiled by the Secretariat, included more than governments themselves notified to the WTO, especially for Australia, Canada, and the United States, although the United States was able to notify some sub-federal level subsidies to the WTO. Our comparison in Appendix 3 includes reports to the G-20, since leaders have called for voluntary reporting and peer review. The G-20 data are also inadequate, finding only 35 measures thought to fall within the reporting obligation, because states are required to report only on inefficient fossil fuel subsidies that contribute to wasteful consumption, which is of course open to interpretation. Some inconsistencies between the G-20 and the WTO are puzzling, perhaps owing to the differing definitions, or the nature of subsequent surveillance. We see detailed reporting of fossil fuel subsidies by Japan in the SCM Committee, but in the G-20, Japan reports that it has no inefficient fossil fuel subsidies. By contrast, Argentina, Canada, Indonesia and Italy reported fossil fuel subsidies to the G-20, but not to the WTO.

One of the strengths of the WTO is the opportunity for Members to hold each other to account, for example by reviewing subsidies notifications in the SCM Committee.

As Table 1 shows, our probe of the most recent five years' experience in the committee found that Members did raise questions about fossil fuel subsidies notification. Some questions were related to the identification of beneficiaries of the subsidies and eligibility criteria, information that according to the WTO questionnaire should have been provided with the notification, but the committee has not yet had a thorough discussion of fossil fuel subsidies. While not directly relevant to the focus of this paper, we note in passing that the record of notification and surveillance of renewable energy subsidies is somewhat stronger, as is shown in the three right columns of Table 1 .

Both the rate of notification of fossil fuel subsidies and the paucity of questions in the committee are no doubt a reflection first of the ambiguities with respect to the definition of subsidies discussed above, and of the usual 'glass house' syndrome. Members do notify some fossil fuel subsidies (perhaps those that are least likely to be challenged?), and they do ask for more detailed information on the notified support measures. If the information available from the WTO was comprehensive in its coverage of countries and measures, this paper would not be necessary. But the information on fossil fuel subsidies is inadequate, as it is for subsidies generally (on the inadequacy of subsidies notification in general, see Collins-Williams and Wolfe, 2010).

In sum, the WTO already discusses fossil fuel subsidies, but inconsistently and based on data that are less complete than those available to other international organizations, but it has a treaty-based definition of 'subsidy', and robust surveillance mechanisms that could be better used. If we wish to improve discussion of fossil fuel subsidies, we need to think about how to improve the data available, but the prior question is where such data could be used at the WTO. In the next section, we discuss why the SCM Committee is not a candidate. 
Table 1. Questions asked about fossil fuel subsidies programs and renewable energy subsidy programs in the SCM Committee, 2008-2013

\begin{tabular}{|c|c|c|c|c|c|c|}
\hline Countries & $\begin{array}{l}\text { Fossil Fuel } \\
\text { Subsidies } \\
\text { (FFS) } \\
\text { notified }\end{array}$ & $\begin{array}{l}\text { Questions } \\
\text { received } \\
\text { about FFS }\end{array}$ & $\begin{array}{l}\text { Questions } \\
\text { asked } \\
\text { (of others) } \\
\text { about FFS }\end{array}$ & $\begin{array}{l}\text { Renewable } \\
\text { energy (RE) } \\
\text { subsidies } \\
\text { notified }\end{array}$ & $\begin{array}{l}\text { Questions } \\
\text { received } \\
\text { about RE } \\
\text { subsidies }\end{array}$ & $\begin{array}{l}\text { Questions } \\
\text { asked (of others) } \\
\text { about RE } \\
\text { subsidies }\end{array}$ \\
\hline Albania & 1 & 0 & 0 & 0 & 0 & 0 \\
\hline Australia & 3 & 0 & 3 & 3 & 2 & 1 \\
\hline Brazil & 1 & 1 & 1 & 0 & 0 & 2 \\
\hline Canada & 0 & 0 & 2 & 4 & 1 & 3 \\
\hline China & 0 & 0 & 0 & 3 & 1 & 0 \\
\hline Costa Rica & 0 & 0 & 0 & 1 & 0 & 0 \\
\hline European Union & 7 & 2 & 2 & 38 & 3 & 6 \\
\hline India* & 11 & 1 & 5 & 0 & 0 & 2 \\
\hline Japan & 13 & 3 & 0 & 5 & 6 & 2 \\
\hline Korea & 1 & 1 & 0 & 0 & 0 & 0 \\
\hline Mexico & 2 & 1 & 0 & 0 & 0 & 0 \\
\hline Norway & 1 & 0 & 0 & 3 & 0 & 0 \\
\hline Peru & 1 & 0 & 0 & 0 & 0 & 0 \\
\hline $\begin{array}{l}\text { Russian } \\
\text { Federation }\end{array}$ & 1 & 0 & 0 & 0 & 0 & 0 \\
\hline Taiwan & 2 & 1 & 0 & 0 & 0 & 1 \\
\hline Turkey & 0 & 0 & 1 & 0 & 0 & 1 \\
\hline Ukraine & 1 & 1 & 0 & 0 & 0 & 0 \\
\hline United States & $\begin{array}{c}14 \\
(8 \text { federal })\end{array}$ & 5 & 2 & $\begin{array}{c}69 \\
(6 \text { federal })\end{array}$ & 11 & 6 \\
\hline Totals & 59 & 16 & 16 & 126 & 24 & 24 \\
\hline
\end{tabular}

Note: * All fossil fuel subsidy programs in the Indian notification G/SCM/N/220/IND of 11 May 2012 were state-level programs providing fuel subsidies to fishermen.

Source: SCM Committee minutes G/SCM/M/62 through G/SCM/M/84.

\section{What happened to 'non-actionable' subsidies in the WTO?}

The WTO struggles with disciplines on subsidies. On the one hand, subsidies have the potential of creating unfair competitive advantages, leading to trade distortions. On the other hand, subsidies can be a useful instrument for economic and social purposes. Unfortunately, Members do not always agree on which is which. Both the ASCM and the Agreement on Agriculture use a traffic light system. In Agriculture, Article 7 and Appendix 2, known as the Green Box, cover domestic support that is thought to be 'minimally trade distorting'. The analog in the ASCM was Article 8 on 'non-actionable' subsidies, but that provision of the agreement has lapsed. A revived Article 8 that included energy subsidies is one of the possible mechanisms that would allow Members to notify their fossil fuel subsidies in a way that would increase the availability of information, and provide the basis for discussion on such subsidies in the SCM Committee. 
While a revival of the category of non-actionable subsidies is often discussed within the context of government support for renewable energy (Howse, 2010), in this section we explore whether a revival of Article 8 would be a way to bring more information on fossil fuel subsidies to the SCM Committee. ${ }^{5}$ Notification of a measure as potentially non-actionable would not shield it from challenge in the Committee or the dispute settlement system. ${ }^{6}$ Such notification would not increase the risk of a complaint (we discuss transparency and the risk of disputes below) but it would allow Members to discuss whether the harm to or benefit for the planet of a particular subsidy is a relevant policy consideration. In this section, we review the negotiating history of Article 8 , concluding that a revival is improbable.

From the start, the Uruguay Round negotiations that created the ASCM reflected ideological differences among Members on subsidies. The United States, unlike other leading Members, such as the EU, Switzerland, and Canada, had never been in favour of subsidization in general because of possible market distorting effects (Stewart, 1993: 875-877). But negotiators recognized that because subsidies can be used to correct market failures and can be desirable when pursuing certain economic and social objectives, not all subsidies should be prohibited or subject to countervailing duties (GATT, 1987b). In the early days of the Uruguay Round, doubts were even raised as to whether Members would give up their sovereign right to use subsidies (GATT, 1987b: 3).

In 1988, Switzerland proposed a traffic light approach, establishing three categories of subsidies, and attaching different legal effects to each of them (GATT, 1988b; Croome, 1998). A first category consists of export subsidies and local content subsidies that are aimed at giving domestic industries competitive advantages. These subsidies would be prohibited. A second category consisted of actionable subsidies and could be subject to countervailing duties when it has been established that material injury is caused. A third category was the 'green light' category and consisted of subsidies that do not have a trade-distortive effect or that should be allowed because they serve a purpose that would be accepted as legitimate.

While there was naturally a relatively broad consensus on the non-actionability of generally available subsidies, perhaps because they were considered to have a minimally distortive effect on trade, the list of other non-actionable subsidies was more problematic (GATT, 1989d; GATT, 1989e; GATT, 1990a). Some negotiators questioned why the 'green light' category had to exist in the first place (GATT, 1989c); some wanted a strict definition of non-actionable subsidies, and others

5 Other suggestions to include fossil fuel subsidies under WTO negotiations have been made. For example, in the negotiations on environmental goods and services, one can argue that fossil fuel subsidies are an important barrier to the development of renewable energy-related goods and their dissemination; they could therefore be addressed under the barriers to environmental goods and services (Howse, 2010).

6 A subsidy notified under Article 8 presumably would not be subject to the disciplines of the ASCM because it was taken for specific purposes that were allowed, but the Article 8 - status of the measure could always be challenged by other Members. 
advocated for a broad category in which the intent of a subsidy has to be taken into account when assessing its non-actionable status. Other Members underlined the need for taking the effect of a subsidy into account, not its intent (GATT, 1988a; GATT, 1988c: 11). Developing countries wanted to include structural adjustment subsidies under the non-actionable category (GATT, 1989f); other countries did the same for regional subsidies, and the EC, Canada, and Switzerland were strongly in favour of carving out environmental subsidies and R\&D subsidies (GATT, 1987a; GATT, 1989a; GATT, 1989b; GATT, 1989g; GATT, 1989h).

During preparations for the Brussels Ministerial Conference in 1990, the United States remained strongly opposed to the category of non-actionable subsidies (Croome, 1998: 173-174), while the EC pursued a more nuanced perspective in the sense of being prepared to allow subsidies with no significant effect on international trade (Stewart, 1993: 875-877). The US approach to non-actionable subsidies changed after Bill Clinton became President in 1993. The general view that subsidies were bad was more nuanced than before because the new administration saw R\&D as particularly important for the US economy (Doane, 1995). This shift in the position of the United States helped to facilitate a conclusion to the negotiations on the ASCM.

Uncertainty about the non-actionable category was reflected in Article 31, which required a review after five years with a determination of whether to extend or modify Article 8. In the last meeting of the SCM Committee before the 1999 Ministerial Conference in Seattle, some Members (e.g., Switzerland and Canada) worried that not extending Article 8 would give the wrong signal to the public and would 'reduce the ability of the ASCM to address environmental concerns' (Bigdeli, 2011: 9). Several developing country Members countered that extension of the provision in its present form would be unacceptable since the category provided advantages only for developed countries (WTO, 1999). The United States had mixed views on the extension, noting that in the five years of its provisional application, no non-actionable subsidy had been notified (Bigdeli, 2011). In the absence of consensus, the category lapsed almost unnoticed shortly after the 1999 Seattle Conference.

Members showed little interest in negotiations on any subsidies issues during the Doha Round, with the exception of fisheries subsidies, but Venezuela, Cuba, and the EU each submitted proposals on non-actionable subsidies. The proposal of Venezuela emphasized that Article 8 could not be reactivated without modification to ensure that developing country structural adjustment subsidies would not be subject to countervailing measures or challenges in a dispute (WTO, 2002a). Developed countries were skeptical of the proposal, and other developing countries argued that the provision would have to be reformulated and be more balanced with regards to the interest of developing countries (WTO, 2003a; WTO, 2003b; WTO, 2003c). The EU proposal to reactivate Article 8 started from the perspective of why the category was never used (WTO, 2002b). The discussions quickly showed that the diverging opinions that were already present in the 
Uruguay Round negotiations had not disappeared. Similarly, the discussions on fisheries subsidies, where some proposals were made to classify 'good' and 'bad' subsidies, resulted in the same outcome: countries could not agree on the classification criteria and expressed considerable scepticism about whether the real purpose of the proposal was conservation of fish stocks, not the effects of subsidies on trade.

The different opinions on which subsidies could be considered non-actionable and which ones not indicate that a revival of the non-actionable category only for the purpose of environmental subsidies would be difficult, and would inevitably lead to long negotiations with all kinds of other subsidies proposed for the nonactionable category (Horlick, 2013). And yet this history shows that negotiators have long understood that subsidies that have an environmental effect are an issue. For years after the lapse of Article 8 it seemed that governments acted as if the provision was still in place; that is, Members understand the logic of why certain subsidies ought to be non-actionable, and have acted accordingly. Until 2010, cases on energy-related subsidies were rare, perhaps reflecting a tacit agreement not to challenge programs designed to promote renewable energy (Rubini, 2012). That tacit agreement now seems fragile.

\section{Role of the Trade Policy Review Mechanism (TPRM)}

With no prospect of restoring the non-actionable category to the ASCM, a helpful alternative forum to generate more information about fossil fuel subsidies with an opportunity for discussion is the Trade Policy Review Body (TPRB). ${ }^{7}$ The central objective of the TPRB is 'to contribute to... the smoother functioning of the multilateral trading system, by achieving greater transparency in, and understanding of, the trade policies and practices of Members'. The TPRB generates three sorts of reports - the periodic Trade Policy Review (TPR) of each Member (WTO, 2011a: paras. $178 \mathrm{ff}$.), the annual review of the state of the trading system, and the monitoring reports on measures taken in response to the financial crisis. In these reports to the TPRB, issued on the authority of the Director-General, not Members, the Secretariat sometimes warns or expresses worries on the basis of its analysis, but never criticizes Members explicitly, and never comments on their rights and obligations under the WTO agreements. Discussion in the TPRB therefore does not imply either that a measure is or is not actionable.

\footnotetext{
7 Robert Howse has recently suggested that the SCM Committee could adopt an interpretive statement creating policy space for renewable subsidies (Howse in ICTSD, 2013), something surely not needed by fossil fuel subsidies, but we do think that the harm to the trading system from fossil fuel subsidies is sufficiently ambiguous that increased opportunities for transparency and surveillance should be found, rather than waiting for more disputes.
} 
Monitoring subsidies falls within the mandate of the TPRB. Subsidies, called 'General Economic Support Measures', have been a particular concern in the crisis monitoring exercise because they clearly increased after September 2008, with undoubted effects on the trading system for good as well as ill, but neither the SCM Committee nor the TPRB has enough data to form a complete picture. Annex 4 of the most recent annual monitoring report (WTO, 2012c) is a valiant attempt, but the Secretariat observed that assessment is inevitably biased because of the paucity of information provided by Members, sometimes because they claim that the relevant supports are not 'new measures' and hence not covered by the process. The TPR reports on individual Members face the same difficulty. Data on support measures are found in various sections of the reports rather than in one place. While the reports are among the few sources of systematically collected subsidies data, they are not strictly comparable, the Secretariat observes, because the absence or presence of data in the report on any one country may be an artifact of the information problems, rather than an indication that the member does or does not maintain such subsidies (WTO, 2012c: para. 118).

The reports already take notice of energy subsidies. Indonesia's energy consumption subsidies are large, and well known, at close to $29 \%$ of central government spending in one recent year (WTO, 2013c: para. 1.11). The TPR report by the Secretariat includes information on energy subsidies and the problems of their reform that were not included in the report that was prepared by Indonesia. In a recent periodic monitoring report, Annex 4 on 'General Economic Support Measures' in the Director-General's annual monitoring report (e.g. WTO, 2012c) is a valiant attempt, but the Secretariat observed that assessment is inevitably biased because of the paucity of information provided by Members, sometimes because they claim that the relevant supports are not 'new measures' and hence not covered by the process. There is a confirmed Brazilian subsidy program for ethanol mentioned, and an unconfirmed US tax credit for the wind power industry (WTO, 2013b: 68 and 72).

Scholars recognize the potential of the TPRM as a forum in which both the trade policies of Members and issues that go beyond trade to include the broader economic policy of a country can be discussed without prejudice to legal compliance with WTO obligations (Chaisse and Matsushita, 2013: 13-14; see also Charnovitz, 2010: 755-756), but opinions diverge about the scope of its mandate and on how to improve the mechanism. Developing countries are hesitant to give the monitoring and surveillance mechanisms in the WTO more weight out of a fear that the bigger, more powerful Members would prescribe their trade policies (Ghosh, 2010). Some academics consider the current mandate too restrictive (Ghosh, 2010: 437-438), others hold that the TPRM within its current mandate can be improved with respect both to information gathering and the participation of civil society (Zahrnt, 2009: 11-12). The Director-General stretched the mandate in 2009 to justify monitoring measures related to the financial crisis as requested by the G-20 (Wolfe, 2012). In 2011, the Ministerial Conference formally recognized the crisismonitoring exercise and asked that it be continued and strengthened (WTO, 2011b). 
The core of each TPR report is based on the notifications from Members, but each report depends on a far wider range of information. The Secretariat collects data from official sources (questionnaires to Member under review) and nonofficial sources, including from other international organizations, media reports, and NGOs (Ghosh, 2011: 431; Chaisse and Matsushita, 2013; Hoekman, 2011: 18-19). To ensure accuracy, the Secretariat seeks verification of the data from nonofficial sources when discussing the draft of its report with the Member (WTO, 2011a: para. 180).

The crisis monitoring reports and annual reports on the trading system use a similar method. The 2012 monitoring report notes that responses were received from around $60 \%$ of the 43 delegations (counting the EU as one) who were asked to verify information received from other sources (WTO, 2012c: para. 19). Many delegations either verify the information, or provide more accurate information, but some responses are less helpful: certain delegations request the Secretariat to delete all information because the measures are not based on legal instruments, or they simply refuse to verify any information whose source is the public media (WTO, 2013b: 21). In such cases, the Secretariat cannot use the data, but if they have evidence that a disputed measure is based on legislation, or if a delegation fails to respond to a request for verification, the measure will be still included in reports as 'unverified'.

We think that all three sorts of TPR reports ought to have a specific section on fossil fuel subsidies. Given the poor record of notification on subsidies in general, and the ambiguities about whether subsidies that might not be specific even ought to be notified, the Secretariat needs help in generating the data from non-WTO sources.

\section{Do notifications put members at risk of disputes?}

Why are Members reluctant to verify third-party data? One of the 'urban myths' of the WTO is that what other Members do not know cannot be the subject of a dispute, and hence Members are reluctant to allow potentially embarrassing information to be made available. The evidence does not support this fear. Some research has been conducted on the relation between the TPRM and complaints in the dispute settlement system. One study compared disputes filed by the NAFTA countries with the respective TPRs. The results showed that the number of measures identified in the TPRs for which a complaint was filed was low, which could indicate that the more measures are notified and subsequently discussed in the TPR, the less likely that they lead to formal disputes (Froese, 2012). Another study of a wider range of disputes found that about half of the measures in dispute settlement complaints could be found in the TPR reports, but only $15 \%$ of the mentions in a TPR report had any detailed policy analysis or criticism of the policy at issue (Ghosh, 2010: 441).

The likelihood of disputes is also diminished by the complexities of making a complaint in the dispute settlement system, which impose high hurdles for all 
Members. Having found a possible problem, Bown (2011: 170) argues, a firm and its advisers must ask:

(1) What is the likelihood of a WTO finding of a legal inconsistency of any particular measure?

(2) How large is the lost foreign market access at stake?

(3) Was this WTO violation a sufficiently important economic cause of lost foreign market access?

(4) What is the legal-political likelihood as well as the form of compliance of the respondent with any WTO rulings?

As Bown shows, the analytic and financial resources needed to answer these questions are significant (Bown, 2009: $104 \mathrm{ff}$ ). In the case of crisis monitoring, where the Secretariat reports go well beyond formal notifications, they 'generated few additional details that could be used by an analyst to help determine whether such a measure was an economically important cause of a reduction to its country's exports' (Bown, 2011: 166).

We believe that increased discussion of fossil fuel subsidies, or any kind of energy subsidies for that matter, is not likely to lead to an increase in conflict among Members. The greater risk is that Members will fail to pick up on the data made available in a TPR. The more the information on fossil fuel subsidies is linked to a potential (negative) trade effect, the more likely it is to be discussed among WTO Members. The more questions that are asked in Geneva, and the more governments at home are asked to justify their policies, the greater the prospects for subsidy reform. The next question is whether third parties, like NGOs, can help in making more information available.

\section{The role of NGOs and third-party notification}

Many international organizations make use of third-party data (Mitchell, 1998). Of particular relevance, many NGOs have a recognized role in contributing to the work of multilateral environmental agreements (MEAs) where they can enhance the knowledge base available to the MEA (Oberthür et al., 2002). Of course, many of the relevant NGOs are based in or funded from the G7 countries, which makes the emerging economies wary (Kahler, 2013: 719), but their role can be essential. One of the strengths of the Convention on International Trade in Endangered Species of Wild Fauna and Flora (CITES) is its ability to work closely with Trade Records Analysis of Flora and Fauna in Commerce (TRAFFIC), an NGO whose purpose is essentially to support CITES by providing information on illegal trade in endangered species (Oberthür et al., 2002; Wolfe and Baddely, 2012: 7-12). Other examples include Greenpeace International providing information on illegal trade to the Secretariat of the Basel Convention on Transboundary Movements of Hazardous Wastes and their Disposal (Okaru, 2011), or Greenpeace and the WWF providing information to the scientific body of the UNFCCC. The Alternative 
Fluorocarbon Environmental Acceptability Study provides information on the production of ozone-depleting substances used by Parties to the Montreal Protocol. Finally, the Ramsar Convention has concluded several memoranda of cooperation with NGOs and has given certain duties to the International Union for Conservation of Nature (IUCN) (Oberthür et al., 2002).

Independent researchers can generate useful reports on fossil fuel subsidies from publicly available data - see for example Oosterhuis (2013) - but the effort can be resource-intensive. Nevertheless, as long as data exist in the public domain, anybody who understands subsidies and taxes (and the local language, if important) can put together a set of estimates. One obvious source of data is the OECD, as suggested by Tim Josling and Klaus Mittenzwei (2013) in an approach to the problem of incomplete and late notification of agriculture subsidies. They argue that OECD Producer Support Estimates (PSE) data on farm subsidies are complementary to WTO notification data, despite the slightly differing conceptual bases. A virtue of exploiting that complementarity would be the ability to calculate provisional or 'pre-notifications' (synthetic notifications for years for which official notifications are not yet available) from recent OECD data, since the OECD dataset is updated autonomously, and nearly continuously, meaning its data are much more timely than WTO agriculture notifications. The issue has apparently provoked lively debate in the TPRB, participants say, since developing countries led by Brazil and India argue that the WTO should not use OECD data (WTO, 2009). However, that should not stop NGOs from doing so.

Where information is incomplete or unclear, NGOs can resort to 'provocative notification', a process of notifying what information is available or has been dug up. Where this information is incorrect-and in particular where it suggests subsidies larger than they are in reality - this kind of notification provides an incentive for the country in question to provide the correct information, if only to counter the impact of the flawed NGO notification. The GSI's reporting of EU biofuel subsidies provoked the Commission to respond by giving more accurate and up-to-date figures than those available to the GSI (Charles et al., 2013). The transparency objective had been achieved.

In the WTO, NGOs can contribute as knowledge brokers helping to facilitate the discussion between Members and contribute to better policies (Perez-Esteve, 2012). In the dispute settlement system, this function is already formalised by allowing NGOs to submit amicus curiae briefs. NGOs also have a role to play, however, before issues reach the dispute settlement phase. Guidelines adopted by the General Council in 1996 (WTO, 1996) include the possibility of 'informal arrangements to receive the information NGOs may wish to make available for consultation by the interested delegations'. While no formal process exists (yet) for NGOs to submit notifications, and the general economic support measures identified in the context of the trade monitoring exercise are not included in the public database, the Secretariat does use NGO data that are relevant. For example, in the crisis monitoring undertaken by the TPRB, the Secretariat makes use of data published 
by Global Trade Alert (Wolfe, 2012; Wolfe, 2013). WTO rules for engagement with NGOs are unlikely to become more formal (Pandey, 2013), but current rules do allow sufficient scope for NGOs to provide information on energy subsidies in a form that would be useful for the WTO. We know that if an NGO provides good data, the Secretariat can and will use it. The 2014 TPR report on Malaysia has an extensive discussion of energy subsidies, over half the total (WTO, 2014). The report draws heavily on third-party information, notably a report by our GSI colleagues (IISD, 2013).

\section{Proposal for a new template for notification of fossil fuel subsidies}

If information provided by an NGO is to be useful, it has to be in the language of the WTO; that is, the data must fit the ASCM definition of subsidy, must be comparable across measures and countries, and must use a standard template comparable to a WTO notification. The information in a WTO notification is the answer to a question posed implicitly or explicitly by a WTO agreement. The generic definition of a notification in the WTO Glossary is 'a transparency obligation requiring member governments to report trade measures to the relevant WTO body if the measures might have an effect on other Members'. In most cases, the notification is structured by a questionnaire or template developed by the relevant body, and increasingly the resulting data are being placed in the new Integrated Trade Intelligence Portal (I-TIP), a publicly available and searchable database.

The virtue of templates is that their use ensures that the same types of data are collected for every Member, and every subsidy, and that the results can be compiled in a database that allows simple comparison and aggregation. If NGOs are to contribute data on energy subsidies, they must provide it in such a standard format. Having a template helps provide a clear path for researchers. As more people use it and test it, there is a double dividend: feedback helps improve estimation and reporting methods, and the data become more comparable across different studies - which can only happen if the WTO or some other body ensures that all such third-party notifications are publicly available.

Our colleagues in the Global Subsidies Initiative (GSI) have long argued that the subsidies questionnaire used by the SCM Committee (discussed above) is inadequate, and have proposed a template for governments to use in preparing subsidies notifications to the WTO in a more structured and consistent manner (Steenblik and Simón, 2011). The GSI encouraged governments to use the template for their notifications to the WTO, and carried out a project to assess and organize German subsidies using the template (Thöne and Dobroschke, 2008). For reasons discussed elsewhere (Wolfe, 2013: 18-19), WTO notification remains weak, and Members do not use the template. When voluntary reporting by governments does not work because they seemingly lack the incentive to notify, third parties have a role to play in identifying and collecting information about subsidies that would be 
accessible in the WTO format (Thöne and Dobroschke, 2008: 23-24). We think that NGOs and individual researchers could use a modified version of the GSI template, particularly in countries with good budgetary transparency or countries in which information is available from other international organizations (whether NGOs have sufficient means to notify this information to the WTO is a question we have yet to explore.)

The GSI is concerned with fossil fuel subsidies and energy subsidies more broadly because of their effect on environmental quality, economic development, governance, and hence on sustainable development in general. The GSI therefore applies an expansive meaning to fossil fuel subsidies, but one based on the definition of a subsidy formulated in the ASCM - see the checklist in Appendix 1 below. The main difference with the ASCM is that the GSI does not include a benefit analysis (ASCM Article 1.1(b)) when identifying energy subsidies, nor does it limit its research to specific subsidies (Article 2). Consequently, a broad range of economic support measures are included in the GSI's work, including both production and consumption subsidies.

The template that we propose in Appendix 2 is thus based on the WTO definition, taking into account the subcategories that the GSI developed to facilitate the understanding of the definition. While initially developed by the GSI for use by governments, this template as modified can serve as the basis for notifications of fossil fuel subsidies by NGOs.

The proposed template contains two parts. The notification summary in the first part provides a quick overview of what different subsidization programs look like in a given country, organized in a table according to a chosen classification system. The Harmonized System (HS), which would organize subsidies by product, has the advantage of being familiar to most WTO Members. The International Standard Industrial Classification of All Economic Activities (ISIC) would allow organization of energy subsidies by economic activity (Steenblik and Simón, 2011). National account statistics of countries are already often structured according to economic activity (agriculture, fishing, mining, manufacturing, retail, etc.). Using ISIC also offers the advantage of having a discussion on subsidies where Members can immediately compare the amount of subsidies related to a particular economic activity, rather than to a product. Finally, when subsidies are organized according to the ISIC system, Members could discuss what kinds of activities related to fossil fuels they do not consider problematic and those that they do, which should be subject to reductions.

The second part is a detailed description by subsidy program of the conditions and objective of the subsidy. The checklist of energy subsidies (Appendix 1) allows researchers to identify consumption and production subsidies for fossil fuels, as well as subsidies for renewable energy (Beaton et al., 2013). The type of subsidy will subsequently determine the method of measuring the amount. For example, direct government expenditure can easily be defined by looking at the government's budget, while tax exemptions have to be measured against a reference level. 
The concept of 'price support' in WTO jurisprudence includes direct government intervention in the market intended to fix the price of a good at a particular level, for example, through the purchase of surplus production when price is set above the market-clearing level (see WTO, 2012d: para. 7.85).

In line with the GSI approach, our template does not ask if a subsidy is specific - a judgment that in the end can only be made by Members through questions in the SCM Committee or the dispute settlement system on a case-by-case basis. Our objective, and a further reason for using the TPRM, is to shine a light on all subsidies that cause market distortions and therefore have an impact on the trading system. Any support measure from a central or sub-central government that is applicable to natural gas, oil, coal, or peat will fall under that category and could be notified by an NGO. We have found in examining subsidy notifications that Members hardly ever provide data to calculate the trade effect of a subsidy, but some discussion on this point will be essential in each case in order to help Members see the WTO relevance of the measure. Both consumer and producer fossil fuel subsidies have an effect on the trading system. Producer subsidies provide a competitive advantage to the recipient. Consumer subsidies favour local industries that are energy intensive. If energy as an input becomes cheaper through fossil fuel subsidization, the producers of energy intensive goods will gain an advantage.

Providing for the amount of a subsidy in the notifications would allow for better discussions. Small subsidies might not be a concern to other Members, while very large subsidization programs might provoke questions and debate. Direct government expenditure will be easier to measure than tax exemptions. NGOs can rely on different methods to calculate subsidies or rely on the data of the OECD, IMF, and IEA to provide the information for this column.

Finally, verification by the Secretariat will be easier if the NGO notification contains the source of the information, including legislative authority for the measure, and any other documentary evidence. The notification should also contain the source for any quantitative data or the calculation of the amount of a subsidy.

\section{Conclusion: shining a light on fossil fuel subsidies}

Trade and the environment are entwined, and one nexus is subsidies. The preamble of the WTO Agreement records Members' commitment to enhanced trade 'allowing for the optimal use of the world's resources in accordance with the objective of sustainable development'. Our aim in this paper was to consider the role of transparency in advancing toward this goal of a trading system that meets the needs of the present without compromising the ability of future generations to meet their own needs. This preambular goal remains hard to define in legal obligations, even if new negotiations were in prospect, but we think Members can nevertheless hold themselves accountable for progress in this direction. We think 
that civil society can help, as it did in the long process of developing the information and analysis to underpin the framing of fisheries subsidies as an appropriate subject for negotiations in the WTO.

Fossil fuel subsidies offer an example of a significant climate change problem where new trade rules are unlikely in the short term, and where an NGO contribution to increased transparency could make a difference. Fossil fuel subsidies divert precious resources from other pressing needs and add colossal sums to national debt. These perverse subsidies provide a strong incentive to prefer carbonbased fuels to the alternatives, and they affect resource allocation in ways that are unfavourable to other, cleaner forms of energy. Their use clearly affects patterns of international trade, even if specific harm to trading partners is not always easily identified. The ASCM ought to be a useful tool to discipline such subsidies, but this agreement is not effective: Members either fail to notify their subsidies, or notify only sporadically. As a result, harmful subsidies continue to undermine sustainable development and the WTO's overall goal remains distant, or even recedes.

We think that imaginative use of existing transparency mechanisms can help. We focus not on the so-called 'enforcement' of precise legal obligations, because the real life of the trading system is elsewhere, and because it is hard to enforce a preamble. This paper therefore offers a proposal on how more information about fossil fuel subsidies can be brought into the WTO as the basis for analysis and further discussion. With more information, Members can learn from each other while publication in TPR reports may help citizens learn that certain kinds of policies in favour of both consumers and producers are in fact perverse subsidies.

Our analysis of the negotiating history of ASCM Article 8, and the broader difficulties in the Doha Round, lead us to conclude that no new provisions for energy subsidies will be added to the WTO any time soon. We must work with what exists, but what exists can make a significant contribution to the analysis of fossil fuel subsidies within the context of both an individual country's trade and economic policy and the effects of subsidies on the trading system. We have found no example of the SCM Committee using third-party notification, so the target for our proposal is the TPRB, but we remain consistent with the definition of subsidies in the ASCM, 'as if' Article 8 were still in force; that is, a Member who wished could use an NGO TPR notification as the basis for a legitimate question in the SCM Committee. We think that the Secretariat should make energy subsidies a separate subsection of every TPR and every monitoring report. Having more comprehensive data can only help discussions about the trade implications of energy subsidies and climate change. Such enhanced surveillance, far from providing raw material for more disputes, will help to clarify the principles and rules applicable to energy, thereby avoiding disputes. And that clarification is essential if the WTO is to be in a position to support rather than obstruct global action to reduce greenhouse gas emissions, one of the defining issues of our time. 


\section{References}

Beaton, C., I. Gerasimchuk, T. Laan, K. Lang, D. Vis-Dunbar, and P. Wooders (2013), A Guidebook to Fossil Fuel Subsidy Reform for Policy-Makers in Southeast Asia, Geneva: Global Subsidies Initiative of the International Institute for Sustainable Development.

Bigdeli, S. Z. (2011), 'Resurrecting the dead? The expired non-actionable subsidies and the lingering question of "green space", Manchester Journal of International Economic Law, 8(2): 2-37.

Bown, C. P. (2009), Self-Enforcing Trade: Developing Countries and WTO Dispute Settlement, Brookings Institution Press.

- (2011), 'Developing countries and monitoring WTO commitments in response to the global economic crisis', in T. Cottier and M. Elsig (eds.), Governing the World Trade Organization: Past, Present and Beyond Doha, Cambridge: Cambridge University Press, pp. 157-187.

Casier, L. and T. Moerenhout (2013), 'WTO Members, not the appellate body, need to clarify boundaries in renewable energy support (IISD Commentary July 2013)', International Institute for Sustainable Development, http://www.iisd.org/pdf/2013/wto_members_renewable_energy_support.pdf.

Chaisse, J. and M. Matsushita (2013), 'Maintaining the WTO's supremacy in the international trade order: a proposal to refine and revise the role of the trade policy review mechanism', Journal of International Economic Law, 16(1): 9-36.

Charles, C., I. Gerasimchuk, R. Bridle, T. Moerenhout, E. Asmelash, and T. Laan (2013), Biofuels - At What Cost? A Review of Costs and Benefits of EU Biofuel Policies, Research Paper April 2013, Geneva: Global Subsidies Initiative of the International Institute for Sustainable Development.

Charnovitz, S. (2010), 'Addressing government failure through international financial law', Journal of International Economic Law, 13(3): 743-761.

Clements, B. J., D. Coady, S. Fabrizio, S. Gupta, T. S. C. Alleyne, and C. A. Sdralevich et al. (eds.) (2013), Energy Subsidy Reform: Lessons and Implications, Washington, DC: International Monetary Fund.

Collins-Williams, T. and R. Wolfe (2010), 'Transparency as a trade policy tool: the WTO's cloudy windows', World Trade Review, 9(4): 551-581.

Cottier, T., G. Malumfashi, S. Matteotti-Berkutova, O. Nartova, J. De Sépibus, and S. Z. Bigdeli (2011), 'Energy in WTO law and policy', in T. Cottier and P. Delimatsis (eds.), The Prospects of International Trade Regulation: From Fragmentation to Coherence, Cambridge: Cambridge University Press, pp. 211-244.

Croome, J. (1998), Reshaping the World Trading System: A History of the Uruguay Round, Geneva: World Trade Organization.

Doane, M. L. (1995), 'Green light subsidies: technology policy in international trade', Syracuse Journal of International Law and Commerce, 21: 155-180.

Froese, M. D. (2012), Between Surveillance and Transparency: Trade Policy Review and North American Dispute Settlement at the WTO, http://ssrn.com/abstract=2038036orhttp://dx.doi.org/10.2139/ ssrn.2038036.

G-20 (2009), G-20 Leaders' Statement: G-20 Leaders Summit, Pittsburgh, 24-25 September 2009, http:// www.g20.utoronto.ca/2009/2009communique0925.html.

GATT (1987a), 'Communication from the EEC', Note by the Secretariat, Negotiating Group on Subsidies and Countervailing Measures, MTN.GNG/NG10/W/7, 11 June 1987.

— (1987b), 'Meeting of 1-2 June 1897', Note by the Secretariat, Negotiating Group on Subsidies and Countervailing Measures, MTN.GNG/NG10/2, 10 June 1987.

— (1988a), 'Checklist of issues for negotiations', Note by the Secretariat, Negotiating Group on Subsidies and Countervailing Measures, MTN.GNG/NG10/W/rev.3, 26 May 1988.

— (1988b), 'Communication from Switzerland', Note by the Secretariat, Negotiating Group on Subsidies and Countervailing Measures, MTN.GNG/NG10/W/17, 1 February 1988.

— (1988c), 'Meeting of 1-3 February 1988', Note by the Secretariat, Negotiating Group on Subsidies and Countervailing Measures, MTN.GNG/NG10/6, 15 February 1988.

— (1989a), 'Communication from Canada', Note by the Secretariat, Negotiating Group on Subsidies and Countervailing Measures, MTN.GNG/NG10/W/25, 28 June 1989. 
(1989b), 'Communication from Switzerland', Note by the Secretariat, Negotiating Group on Subsidies and Countervailing Measures, MTN.GNG/NG10/W/26, 13 September 1989.

- (1989c), 'Elements of the framework for negotiations, Submission by the United States', Negotiating Group on Subsidies and Countervailing Measures, MTN.GNG/NG10/W29, 22 November 1989.

_ (1989d), 'Report of the meeting 26-27 September 1989', Note by the Secretariat, Negotiating Group on Subsidies and Countervailing Measures, MTN.GNG/NG10/37, 16 October 1989.

— (1989e), 'Submission by Australia', Negotiating Group on Subsidies and Countervailing Measures, MTN.GNG/NG10/W/32, 30 November 1989.

— (1989f), 'Submission by India', Negotiating Group on Subsidies and Countervailing Measures, MTN.GNG/NG10/W/33, 30 November 1989.

— (1989g), 'Submission by Japan', Negotiating Group on Subsidies and Countervailing Measures, MTN.GNG/NG10/27, 6 October 1989.

— (1989h), 'Submission by the European Community', Negotiating Group on Subsidies and Countervailing Measures, MTN.GNG/NG10/W/31, 27 November 1989.

— (1990a), 'Report of the Meeting 30 November-1 December 1989', Note by the Secretariat, Negotiating Group on Subsidies and Countervailing Measures, MTN.GNG/NG10/15, 10 January 1990.

Gerasimchuk, I. (2012), Fossil Fuels-At What Cost? Government Support for Upstream Oil and Gas Activities in Russia, February, Moscow/Geneva: WWF Russia-IISD.

Ghosh, A. (2010), 'Developing countries in the WTO Trade Policy Review Mechanism', World Trade Review, 9(3): 419-455.

_ (2011), 'Strengthening WTO surveillance: making transparency work for developing countries', in C. Deere-Birkbeck (ed.), Making Global Trade Governance Work for Development: Perspectives and Priorities from Developing Countries, Cambridge, New York: Cambridge University Press, pp. 394-441.

Global Subsidies Initiative (GSI) (2013a), 'Fossil fuel-at what cost?', Global Subsidies Initiative of the International Institute for Sustainable Development, Geneva, http://www.iisd.org/gsi/fossil-fuelsubsidies/fossil-fuels-what-cost.

— (2013b), Global Subsidies Initiative of the International Institute for Sustainable Development, Library of official G-20 documents and related reports, Geneva, http://www.iisd.org/gsi/libraryofficial-g-20-documents-and-related-reports-0.

Hoekman, B. (2011), Proposals for WTO Reform: A Synthesis and Assessment, January, World Bank and CEPR.

Horlick, G. N. (2013), 'Solar energy wars-and peace', Working Paper, Think Piece for the E15 Expert Group on Clean Energy, International Center for Trade and Sustainable Development.

Howse, R. (2010), Climate Mitigation Subsidies and the WTO Legal Framework: A Policy Analysis, Winnipeg: International Institute for Sustainable Development.

International Institute for Sustainable Development (IISD) (2013), A Citizens' Guide to Energy Subsidies in Malaysia, Winnipeg: International Institute for Sustainable Development, Global Subsidies Initiative, May 2013.

International Centre for Trade and Sustainable Development (ICTSD) (2011), Fostering Low Carbon Growth: The Case for a Sustainable Energy Trade Agreement, ICTSD Global Platform on Climate Change, Trade and Sustainable Energy, Geneva.

- (2013), Clean Energy and the Trade System Group: Proposals and Analysis, Geneva.

International Energy Agency (IEA) (2013), Fossil Fuel Subsidies-Methodology and Assumptions, http://www.iea.org/publications/worldenergyoutlook/resources/energysubsidies/ methodologyforcalculatingsubsidies/

Jones, D. and R. Steenblik (2010, June), Subsidy Estimation: A Survey of Current Practice, The Global Subsidies Initiative of the International Institute for Sustainable Development.

Josling, T. and K. Mittenzwei (2013), 'Transparency and timeliness: the monitoring of agricultural policies in the WTO using OECD data', World Trade Review, 12(3): 533-547.

Kahler, M. (2013), 'Rising powers and global governance: negotiating change in a resilient status quo', International Affairs, 89(3): 711-729. 
Koplow, D. (2009), Measuring Energy Subsidies Using the Price-Gap Approach: What Does It Leave Out? International Institute for Sustainable Development, http://www.iisd.org/pdf/2009/bali_2_copenhagen_ff_subsidies_pricegap.pdf.

_ (2012), 'G-20 fossil fuel subsidy reform: flexible definitions make compliance easy', 8 August, http:// www.earthtrack.net/blog/g20-fossilfuel-subsidy-reform-flexible-definitions-make-compliance-easy.

Meyer, T. (2013), 'Energy subsidies and the World Trade Organization', ASIL Insights, 17(22).

Mitchell, R. B. (1998), 'Sources of transparency: information systems in international regimes', International Studies Quarterly, 42(1): 109-131.

Oberthür, S., M. Buck, S. Müller, S. Pfahl, R. G. Tarasofsky, J. Werksman, and A. Palmer (2002), 'Participation of non-governmental organisations in international environmental governance: legal basis and practical experience', Final Report June 2002, Ecologic Institute for International and European Environmental Policy.

Okaru, V. O. (2011), 'The Basel Convention: controlling the movement of hazardous wastes to developing countries', Fordham Environmental Law Review, 4(2): 137-165.

Oosterhuis, F., with contributions from Raluca Alexandru, Andra Blumberga, Viktorija Bobinaite, Jonathan Cauchi, Nataliya Nikolova, and Elissaios Papyrakis (2013), Budgetary Support and Tax Expenditures for Fossil Fuels: An Inventory for Six Non-OECD EU Countries, 15 January, IVM Institute for Environmental Studies.

Organisation for Economic Co-operation and Development (OECD) (2010), OECD's Producer Support Estimate and Related Indicators of Agricultural Support: Concepts, Calculations, Interpretation and Use (the PSE manual), Trade and Agricultural Directorate, OECD, http://www.oecd.org/tad/ agricultural-policies/46193164.pdf.

- (2012), Inventory of Estimated Budgetary Support and Tax Expenditures for Fossil Fuels 2013, OECD Publishing.

Pandey, N. (2013), Global Civil Society and Inter-Governmental Organizations: The Role of NonGovernmental Organizations in the World Trade Organization, New Delhi: Jawaharlal Nehru University.

Perez-Esteve, M. (2012), 'WTO rules and practices for transparency and engagement with CSOs', Staff Working Paper ERSD-2012-14, 18 September, World Trade Organization.

Rubini, L. (2009), The Definition of Subsidy and State Aid: WTO and EC Law in Comparative Perspective, New York: Oxford University Press.

_ (2012), 'Ain't wastin time no more: subsidies for renewable energy, the SCM Agreement, policy space, and law reform', Journal of International Economic Law, 15(2): 525-579.

Steenblik, R. (1998), 'Previous multilateral efforts to discipline subsidies to natural resource based industries', Paper prepared for the Workshop on the Impact of Government Financial Transfers on Fisheries Management, Resource Sustainability, and International Trade, Manila, Philippines, 17-19 August 1998.

- (2010), 'Subsidies in the traditional energy sector', in J. Pauwelyn (ed.), Global Challenges at the Intersection of Trade, Energy and the Environment, London: Centre for Economic Policy Research, pp. 183-192.

Steenblik, R. and J. Simón (2011), A New Template for Notifying Subsidies to the WTO, May, The Global Subsidies Initiative of the International Institute for Sustainable Development, Geneva.

Stewart, T. P. (1993), The GATT Uruguay Round: A Negotiating History (1986-1992), Volume I: Commentary, The Hague: Kluwer Law International.

Thöne, M. and S. Dobroschke (2008, April), WTO Subsidy Notifications: Assessing German Subsidies under the GSI Notification Template Proposed for the WTO, The Global Subsidies Initiative of the International Institute for Sustainable Development.

Wolfe, R. (2012), 'Protectionism and multilateral accountability during the great recession: drawing inferences from dogs not barking', Journal of World Trade (4): 777-814.

(2013), Letting the Sun Shine in at the WTO: How Transparency Brings the Trading System to Life, Staff Working Paper ERSD-2013-03, World Trade Organization.

Wolfe, R. and S. Baddeley (2012), 'Tropical timber, e-waste and diamonds: how transparency makes MEAs work', ENTWINED Issue Brief 13, 24 August. 
World Trade Organization (WTO) (1996), Guidelines for Arrangements on Relations with NonGovernmental Organizations: Decision Adopted by the General Council on 18 July 1996, WT/L/ 62, 23 July 1996.

— (1999), 'Minutes of the Regular Meeting held on 1-2 November 1999', World Trade Organization, Committee on Subsidies and Countervailing Measures, G/SCM/M/24, 26 April 2000.

(2002a), Improved Rules under the Agreement on Subsidies and Countervailing Measures, Proposal by Venezuela, Negotiating Group on Rules, TN/RL/W/41, World Trade Organization, 17 December 2002.

— (2002b), WTO Negotiations Concerning the WTO Agreement on Subsidies and Countervailing Measures, Proposal by the European Communities, Negotiating Group on Rules, TN/RL/W/30, World Trade Organization, 21 November 2002.

- (2003a), Egyptian Paper Containing Questions and Comments on the Contributions Submitted in the Framework of the Doha Negotiations on Subsidies and Countervailing Measures Agreement, Negotiating Group on Rules, TN/RL/W/57, World Trade Organization, 10 February 2003.

(2003b), Preliminary answers of Cuba and Venezuela to the questions provided by Egypt, Negotiating Group on Rules, TN/RL/W/108, World Trade Organization, 13 May 2003.

- (2003c), Preliminary Replies to the Questions by Australia, Submitted by Venezuela and Cuba, Negotiating Group on Rules, TN/RL/W/70, World Trade Organization, 18 March 2003.

- (2003d), Questionnaire Format for Subsidy Notifications under Article 25 of the Agreement on Subsidies and Countervailing Measures and under Article XVI of GATT 1994, Committee on Subsidies and Countervailing Measures, G/SCM/6/Rev.1, World Trade Organization, 11 November 2003. (2006), World Trade Report 2006: Subsidies, Trade and the WTO, Geneva: World Trade Organization.

- (2009), Strengthening the WTO, Communication from India, General Council, WT/GC/W/605, World Trade Organization, 3 July 2009.

- (2011a), 'Overview of developments in the international trading environment: Annual report by the Director-General', WT/TPR/OV/14, World Trade Organization, 21 November 2011.

— (2011b), 'Trade policy review mechanism: decision of 17 December 2011', WT/L/848, World Trade Organization, 19 December 2011.

(2012a), Canada-Certain Measures Affecting the Renewable Energy Generation Sector; Canada-Measures Relating to the Feed-In Tariff Program, Report of the Panels, WT/DS412/R, WT/DS46, World Trade Organization, 19 December 2012.

- (2012b), 'Notification requirements under the Agreement on Subsidies and Countervailing Measures: Background note by the Secretariat', Committee on Subsidies and Countervailing Measures, G/SCM/W/546/Rev.3, World Trade Organization, 12 April 2012.

- (2012c), 'Overview of developments in the international trading environment: Annual Report by the Director-General', WT/TPR/OV/15, World Trade Organization, 29 November 2012.

- (2012d), China - Countervailing and Anti-dumping Duties on Grain Oriented Flat-Rolled Electrical Steel from the United States (China-GOES), Report of the Panel, WT/DS414/R, World Trade Organization, 15 June 2012.

(2013a), Canada-Certain Measures Affecting the Renewable Energy Generation Sector; Canada-Measures Relating to the Feed-In Tariff Program, Reports of the Appellate Body, WT/DS412/AB/R, WTDS426/AB/R, World Trade Organization, 6 May 2013.

(2013b), 'Report to the TPRB from the Director-General on trade-related developments (mid-October 2012 to mid-May 2013)', Trade Policy Review Body, WT/TPR/OV/W/7, World Trade Organization, 5 July 2013.

— (2013c), 'Trade policy review', Report by the Secretariat', Indonesia, World Trade Organization, Trade Policy Review Body, WT/TPR/S/278, World Trade Organization, 6 March 2013.

- (2014), 'Trade policy review', Report by the Secretariat, Malaysia, Trade Policy Review Body, WT/TPR/S/292, World Trade Organization, 27 January 2014.

Zahrnt, V. (2009), The WTO's Trade Policy Review Mechanism: How to Create Political Will for Liberalization? ECIPE Working Paper No. 11/2009, European Centre for International Political Economy. 


\section{Appendix 1. GSI Checklist for identifying energy subsidies}

\begin{tabular}{|c|c|c|}
\hline $\begin{array}{l}\text { Direct and indirect transfer of } \\
\text { funds and liabilities ASCM } \\
\text { Article } 1.1 \text { (a)(1)(i) }\end{array}$ & $\begin{array}{l}\text { Government ownership of } \\
\text { energy-related enterprises } \\
\text { Credit support } \\
\text { Insurance and indemnification } \\
\text { Occupational health and accidents } \\
\text { Environmental costs }\end{array}$ & $\begin{array}{l}\text { Earmarks } \\
\text { Agency appropriations and contracts } \\
\text { Research and development support } \\
\text { Security-related enterprises } \\
\text { Municipal utilities and public power } \\
\text { Government loans and loan guarantees } \\
\text { Subsidized credit to domestic infrastructure and power plants } \\
\text { Subsidized credit to oil and gas related exports } \\
\text { Government insurance/indemnification } \\
\text { Statutory caps on commercial liability } \\
\text { Assumption of occupational health and accident liabilities } \\
\text { Responsibility for closure and post-closure risks } \\
\text { Waste management } \\
\text { Environmental damages }\end{array}$ \\
\hline $\begin{array}{l}\text { Government revenue foregone } \\
\text { ASCM Article } 1.1 \text { (a)(1)(ii) }\end{array}$ & Tax breaks and special taxes & $\begin{array}{l}\text { Tax expenditures } \\
\text { Overall tax burden by industry } \\
\text { Excise taxes/special taxes }\end{array}$ \\
\hline $\begin{array}{l}\text { Income or price support } \\
\text { ASCM Article } 1.1(\mathrm{a})(2)\end{array}$ & Market price support and regulation & $\begin{array}{l}\text { Consumption mandates and feed-in tariffs (FITs) } \\
\text { Border protection or restrictions } \\
\text { Regulatory loopholes } \\
\text { Regulated prices set at below-market rates } \\
\text { Regulated prices set at above-market rates }\end{array}$ \\
\hline
\end{tabular}




\section{Appendix 2. Template for the Notification of Fossil Fuel Subsidies to the WTO}

\section{Notification summary}

\begin{tabular}{|l|l|l|l|l|l|l|l|}
\hline $\begin{array}{l}\text { ISIC } \\
\text { Code }\end{array}$ & $\begin{array}{l}\text { Government } \\
\text { Level }\end{array}$ & $\begin{array}{l}\text { Regional } \\
\text { Designation }\end{array}$ & $\begin{array}{l}\text { Subsidy } \\
\text { Type }\end{array}$ & $\begin{array}{l}\text { Program } \\
\text { Name }\end{array}$ & $\begin{array}{l}\text { Target } \\
\text { Beneficiaries }\end{array}$ & Duration & Amount \\
\hline & & & & & & & \\
\hline & & & & & & & \\
\hline & & & & & & & \\
\hline & & & & & & & \\
\hline
\end{tabular}

\section{Notification appendix}

1. Authority providing the subsidy (state agency involved, and legislative basis where available)

2. Purpose of the subsidy

3. Title of the program

4. To whom and how the assistance is provided

5. Amount - with source for any calculation (e.g. OECD, IEA, IMF, GSI)

6. Duration

7. Potential effect on trade-can be qualitative or quantitative

8. Source of the information

\section{Appendix 3. Comparison of reporting support measures for fossil fuels, 2008-2013}

\begin{tabular}{llll}
\hline \hline Country & WTO SCM notification & OECD inventory & G-20 voluntary \\
\hline Albania & 1 & 0 & 0 \\
Argentina & 0 & 0 & 2 \\
Australia & Fed: 2; state: 1 & Fed: $18 ;$ State: 28 & 0 \\
Austria (EU) & 0 & 7 & 0 \\
Belgium (EU) & 0 & 12 & 0 \\
Brazil & 1 & 0 & 3 \\
Canada & 0 & Fed: $9 ;$ Prov: 67 & 3 \\
Chile & 0 & 4 & 0 \\
Czech Republic (EU) & 0 & 9 & 0 \\
Denmark (EU) & 0 & 7 & 0 \\
Estonia (EU) & 0 & 17 & 0 \\
European Union & 1 & 0 & 0 \\
Finland (EU) & 1 & 18 & 0 \\
France (EU) & 0 & 34 & 0 \\
Germany (EU) & 0 & 28 & 1 \\
Greece (EU) & 0 & 8 & 0 \\
Hungary (EU) & 0 & 7 & 0
\end{tabular}


632 LIESBETH CASIER ET AL.

(Cont.)

\begin{tabular}{|c|c|c|c|}
\hline Country & WTO SCM notification & OECD inventory & G-20 voluntary \\
\hline Iceland & 0 & 1 & 0 \\
\hline India & Sub-federal: 11 & 0 & 4 \\
\hline Indonesia & 0 & 0 & 3 \\
\hline Ireland (EU) & 0 & 3 & 0 \\
\hline Israel & 0 & 4 & 0 \\
\hline Italy (EU) & 0 & 10 & 1 \\
\hline Japan & 13 & 18 & 0 \\
\hline Korea & 1 & 13 & 2 \\
\hline Luxembourg (EU) & 0 & 4 & 0 \\
\hline Mexico & 2 & 6 & 2 \\
\hline Netherlands (EU) & 0 & 6 & 0 \\
\hline New Zealand & 0 & 8 & 0 \\
\hline Norway & 1 & 16 & 0 \\
\hline Peru & 1 & 0 & 0 \\
\hline Poland (EU) & 1 & 16 & 0 \\
\hline Portugal (EU) & 0 & 9 & 0 \\
\hline Romania (EU) & 1 & 0 & 0 \\
\hline Russian Federation & 1 & 0 & 0 \\
\hline Slovak Republic (EU) & 1 & 10 & 0 \\
\hline Slovenia (EU) & 0 & 10 & 0 \\
\hline Spain (EU) & 1 & 9 & 1 \\
\hline Sweden (EU) & 0 & 29 & 0 \\
\hline Switzerland & 0 & 4 & 0 \\
\hline Taiwan & 2 & 0 & 0 \\
\hline Turkey & 0 & 10 & 1 \\
\hline Ukraine & 1 & 0 & 0 \\
\hline United Kingdom (EU) & 1 & 14 & 0 \\
\hline United States & Fed: 8; State: 6 & Fed: 20 State: 147 & 12 \\
\hline Totals: & 59 & 640 & 35 \\
\hline
\end{tabular}

